\title{
KAJIAN STRATEGI OPERASI INDUSTRI KECIL PAKAN IKAN BERBASIS PRODUK SAMPINGAN AGRIBISNIS (KASUS CV. BABELAN AGRO SEJAHTERA BEKASI)
}

\author{
M. Ikhwan Rahmanto \\ Program Studi Agribisnis Universitas Islam “45” Bekasi \\ Jl. Cut Meutia 83 Bekasi 17115 \\ m.ikhwan.rahmanto@gmail.com
}

\begin{abstract}
Abstrak: CV Babelan Agro Sejahtera (CV. BAS) Bekasi adalah salah satu dari sedikit industri kecil pakan ikan. Perusahaan ini masih bertahan di tengah dominasi perusahaan besar dalam persaingan pasar pakan ikan. Tujuan penelitian ini adalah merumuskan strategi operasi industri kecil pakan ikan dalam rangka meningkatkan daya saingnya. Data penelitian ini dikumpulkan dengan pengamatan ke perusahaan, menelaah data sekunder, wawancara mendalam dengan pengelolanya, dan penyampaian kuisioner AHP kepada pengelola perusahaan dan ahli agribisnis atau agroindustri. Evaluasi komposisi dan biaya bahan baku dengan metode simpleks menunjukkan bahwa sebelum minimasi biaya bahan baku pakan ikan sebesar Rp. 2964,00/kg dan setelah minimasi sebesar Rp. 2770,00/kg. Ini artinya CV. BAS dapat mengurangi biaya bahan baku, sehingga strategi mempertahankan harga murah dapat dilanjutkan. Berdasar Matriks Internal-Eksternal, CV. BAS berada pada sel IV (tumbuh dan membangun), berarti perusahaan perlu melakukan strategi integrasi ke belakang, integrasi ke depan, atau integrasi horizontal, penetrasi pasar, pengembangan pasar, dan pengembangan produk. Analisis SWOT menghasilkan 3 alternatif strategi, yaitu mempertahankan harga, peningkatan kapasitas produksi, dan pengembangan SCM. Selanjutnya analisis AHP menyusun prioritas strategi, yaitu : (1) pengembangan SCM, (2) peningkatan kapasistas produksi, dan (3) mempertahankan harga, dimana penerapannya harus memperhatikan 4 kriteria dengan prioritas (1) Kualitas (2) Biaya (3) Fleksibilitas, dan (4) Pengiriman.
\end{abstract}

Kata Kunci: Analisis Hirarki Proses, Analisis SWOT, Metode Simpleks, Strategi Operasi

\begin{abstract}
:
CV. Babelan Agro Sejahtera (CV. BAS) Bekasi is one of few small fish food companies. The company still survives amid the dominance of large companies in the fish food market competition. The purpose of this study is to formulate the operation strategy of small fish food industries to increase their competitiveness. The research data was collected by observation to the company, analyzing secondary data, in-depth interviews with managers, and delivery of AHP questionnaires to the managers of the company and the agribusiness or agroindustry experts. The evaluation of composition and cost of raw materials with the simplex method showed that before minimization the fish foodraw material costs: Rp. $2964.00 / \mathrm{kg}$ and after minimization costs : Rp. $2770.00 / \mathrm{kg}$. This means that the CV. BAS can reduce the cost of raw materials, so the strategy of maintaining low prices can continue. Based on Internal-External Matrix, CV. BAS is in cell IV (grow and build). This means the company should focus on intensive stragety (market penetration, market development, and product development) or integrations strategy (backward integration, forward integration, horizontal integration). SWOT analysis resulted in three alternative strategies : maintained prices, increased production capacity, and the development of SCM. Further analysis of AHP prioritize strategies : (1) the development of SCM, (2) the increase of the production capacity, and (3) maintained price, which application must consider four criteria with priority (1) Quality (2) Costs (3) Flexibility, and (4) Delivery.
\end{abstract}

Keywords: Analitycal Hierarchy Process, Operations Strategy, Simplex Method, SWOT analysis

\section{PENDAHULUAN}

Lingkungan bisnis yang semakin dinamis menyebabkan persaingan antar perusahaan semakin ketat dalam memperebutkan pangsa pasar. Tuntutan konsumen terhadap produk yang berkualitas, spesifikasi yang sesuai, harga yang rendah, dan layanan pengiriman yang cepat harus dipenuhi oleh produsen.

Suasana kompetitif juga terjadi pada bisnis pakan ikan. Pakan ikan diperlukan dalam usaha perikanan budidaya untuk mencukupi kebutuhan nutrisi ikan. Secara umum perikanan budidaya mencakup budidaya laut, 
tambak, kolam, jaring apung, dan sawah. Provinsi Jawa Barat menempati urutan keempat dalam produksi perikanan budidaya, dengan jumlah produksi sebesar 695.104 ton. Khusus untuk perikanan budidaya darat, Provinsi Jawa Barat menempati urutan pertama dengan jumlah produksi mencapai 295.715 ton untuk kolam dan 185.428 ton untuk jaring apung. Kontribusi Jawa Barat sebagai sentra perikanan budidaya darat mencapai $29.48 \%$ dari total produksi perikanan budidaya darat nasional.

Kebutuhan pakan ikan untuk perikanan budidaya darat di Jawa Barat sangat besar. Jawa Barat merupakan konsumen pakan ikan terbesar di Indonesia atau 40 persen dari total kebutuhan pakan ikan nasional. Menurut Indrajaya (2009), dari kebutuhan pakan sebanyak 1,7 juta ton, sekitar 1,6 juta ton di antaranya digunakan untuk budidaya ikan keramba jaring apung (KJA). Potensi pasar pakan ikan di Provinsi Jawa Barat sebagian besar terserap untuk keperluan budidaya ikan keramba jaring apung. Wajar bila banyak produsen pakan ikan yang memiliki jaringan distribusi di sekitar beberapa lokasi keramba jaring apung di atas.

Kabupaten Bekasi - sebagai lokasi perusahaan CV. Babelan Agro Sejahtera (CV. BAS) memiliki potensi perikanan darat yang sangat kecil bila dibanding dengan Provinsi Jawa Barat. Berdasarkan data BPS Provinsi Jawa Barat (2012), potensi perikanan budidaya Kabupaten Bekasi hanya sekitar $0.016 \%$ dari potensi perikanan darat provinsi Jawa Barat, lokasi budidaya perikanan darat di Kabupaten dan Kota Bekasi juga menyebar, sehingga kurang menguntungkan bila dijadikan sebagai sasaran utama pasar pakan ikan produksi CV. BAS.

Perkembangan bisnis budidaya ikan memerlukan dukungan industri penyedia sarana produksi, antara lain industri pakan ikan. Keberadaan dan perkembangan budidaya keramba jaring apung di beberapa waduk di Provinsi jawa Barat telah mendorong perkembangan pabrik-pabrik pakan di daerah Kabupaten/Kota Tangerang, Kabupaten/Kota Bekasi, Kabupaten Bogor, dan Kabupaten/ Kota Cirebon.

Harga pakan ikan produksi perusahaan besar tersebut umumnya sangat tinggi. Menurut Indrajaya (2012), produksi pakan ikan dan udang masih bergantung pada impor. Hingga kini produsen pakan harus mengimpor sampai 70 persen bahan baku. Salah satu bahan baku yang dimaksudkan adalah tepung bungkil kedelai yang diimpor 2,5 juta ton tahun lalu. Bahan baku impor lainnya adalah tepung ikan.

Menurut Azwar (2010), penggunaan bahan baku lokal (BBL) sebagai sumber pakan perlu ditingkatkan, dengan biaya yang murah tentunya dapat mendorong peningkatkan produksi. Selama ini hampir 90 persen pakan yang beredar untuk budidaya ikan dipasok dari industri pakan yang dalam proses pembuatannya mengandalkan bahan baku impor. Ketergantungan bahan baku impor sangat sulit menjaga kestabilan harga pakan, harapan untuk menekan harga pakan adalah mengurangi ketergantungan bahan baku impor, pemakaian masih sangat terbatas, kendalanya karena sulit mendapatkan dalam jumlah besar disamping kualitas tidak stabil. BBL lebih banyak dimanfaatkan oleh pabrikan skala menengah dan kecil karena kapasitas produksi tidak besar dan umumnya dibuat untuk kebutuhan sendiri atau kelompok.

Umumnya pakan ikan diproduksi oleh perusahaan besar yang memiliki kualitas produk standar, jaringan distribusi luas dan modal yang kuat sehingga mampu memberikan fasilitas kemudahan tempo pembayaran. CV Babelan Agro Sejahtera (CV BAS) adalah salah satu dari sedikit industri kecil yang memproduksi pakan ikan. Kondisi ini menuntut CV BAS untuk meningkatkan daya saingnya agar mampu menembus celah pasar.

CV. BAS memiliki obsesi untuk meningkatkan kapasitas produksi dengan tetap memiliki keunggulan baik dari sisi harga, mutu, dan waktu produksi. Permasalahan yang dihadapi adalah belum stabilnya kuantitas dan kualitas bahan baku yang tersedia pada berbagai pemasok, proses produksi kadang tertunda akibat kerusakan mesin produksi, dan pemasaran yang masih terbatas.

Tujuan Penelitian ini adalah (1) merumuskan kombinasi bahan baku pakan ikan yang berkualitas - berbasis produk sampingan perikanan tangkap dan agroindustri, untuk minimasi biaya bahan baku, dan (2) merumuskan strategi pengembangan industri pakan ikan berbasis produk sampingan agribisnis. 


\section{TINJAUAN PUSTAKA}

\section{Industri Pakan Ikan}

Industri pakan ikan yang mampu menghasilkan produk standar dengan harga murah memiliki peluang usaha yang sangat menguntungkan. Karena industri pakan mempunyai peran yang sangat penting dalam budidaya perikanan darat yang dikelola secara intensif mengingat tidak kurang dari $70 \%$ total biaya produksi terserap oleh pakan. Meskipun pertumbuhan industry pakan sangat pesat seiring dengan permintaan komoditas ikan di pasar domestik dan luar negeri, ternyata bangun industrinya dikuasai hanya oleh beberapa perusahaan besar. Kelompok usaha tersebut saat ini mengusasi jaringan bahan baku, prosesing dan pemasaran. Dengan telah dikuasainya jaringan tersebut berdampak langsung pada trend elastisitas harga yang tidak menguntungkan bagi petani. (Srihati dan Sukirno, 2003)

Menurut Handajani dan Widodo (2010) salah satu kelemahan penyusunan pakan ikan selama ini adalah kurang mengoptimalkan potensi pakan lokal. Umumnya sebagain bahan pakan terutama sumber protein masih impor seperti bungkil kedelai dan tepung ikan. Akibatnya harga bahan pakan tersebut relative mahal. Alasan yang umum dipakai untuk pembenaran impor adalah belum adanya bahan pakan tersebut di daerah lokal dan/ atau standarisasi kualitas bahan pakan yang relative stabil. Sementara potensi bahan pakan lokal sampai saat ini belum tergarap dengan baik.

\section{Minimasi Biaya Bahan Baku}

Heizer dan Render (2009), menjelaskan bahwa banyak keputusan manajemen operasi berkaitan dengan usaha menggunakan sumber daya organisasi dengan cara yang paling efektif. Sumber daya biasanya meliputi permesinan, tenaga kerja, uang, waktu, dan bahan baku. Pemrograman linier atau PL adalah suatu teknik matematis yang dirancang untuk membantu para manajer operasi dalam merencanakan dan membuat keputusan yang diperlukan untuk mengalokasikan sumber daya. Salah satu contoh penerapan PL yang berhasil adalah pemilihan bauran komposisi makanan untuk menghasilkan kombinasi makanan
Mengacu kepada temuan Srihati dan Sukirno (2003), bahwa sebagian besar biaya produksi usaha pakan ikan digunakan untuk pengadaan bahan baku yang mencapai $87 \%$ dan $52 \%$ dari biaya bahan baku terserap oleh tepung ikan, maka minimasi biaya bahan baku pakan ikan penting untuk dilakukan melaui pengaturan komposisi bahan baku penyusun pakan ikan.

\section{Manajemen Strategi}

Keunggulan bersaing merupakan dasar bagaimana perusahaan mampu menciptakan nilai untuk pembeli yang melebihi cost yang dikeluarkan perusahaan untuk penciptaan nilai tersebut (Porter, 1985). Lebih lanjut Porter (1985) menjelaskan bahwa ada 5 kekuatan yang menpengaruhi persaingan dalam suatu industri: (1) ancaman masuknya pendatang baru, (2) kekuatan tawar menawar pemasok, (3) kekuatan tawar menawar pembeli, (4) Ancaman produk substitusi, dan (5) persaingan dalam industri. Untuk menyusun rancangan strategi yang baik dan agar dapat menduduki posisi yang kompetitif dalam industrinya maka perusahaan harus dapat meminimumkan dampak kelima kekuatan tersebut.

Hunger dan Wheelen (2010) menjelaskan bahwa manajemen strategik merupakan serangkaian keputusan dan tindakan manajerial yang menentukan kinerja organisasi dalam jangka panjang. Manajemen strategik mencakup scanning lingkungan (eksternal dan internal), formulasi strategi baik bersifat jangka pendek atau panjang, evaluasi dan kontrol. Setiap organisasi harus menggunakan konsep dan teknik manajemen strategis dalam lingkungan industri yang dijalankannya dengan pendekatan proaktif dalam menghadapi berbagai peristiwa.

Menurut Grant (1999) strategi memiliki 3 tingkat, yaitu strategi korporasi, strategi bisnis, dan strategi fungsional. Salah satu strategi yang berada pada strategi fungsional adalah strategi produksi atau operasi. Dalam konteks industri pengolahan, diperlukan strategi manufaktur. Menurut Gaspersz (2005), perencanaan strategic manufacturing lebih sering berhubungan dengan isu-isu internal dari pada isu-isu eksternal. Bagimanapun juga, isu eksternal paling penting yang perlu dipertimbangkan dalam strategi manufacturing adalah isu-isu yang berkaitan dengan pemasok 
(supplier issues) serta pemahaman tentang kebutuhan dan keinginan pelanggan.

Menurut Ellitan dan Anatan (2008) beberapa peneliti menyatakan bahwa strategi manufaktur mewakili prioritas kompetitif. Prioritas kompetitif ini meliputi biaya(cost), kualitas (quality), fleksibilitas (flexibility), dan pengiriman (delivery). Keempat dimensi strategi tersebut bukanlah strategi yang saling meniadakan satu sama lain, tetapi merupakan satu kesatuan yang terpadu dan saling memperkuat. Strategi biaya adalah produksi dan distribusi sebuah produk dengan biaya terendah dan sumber daya tersisa (waste resources) yang minimum. Strategi ini mencerminkan prioritas perusahaan pada efisiensi biaya agar mampu berkompetisi berbasis pada biaya. Strategi kualitas didefinisikan sebagai aktivitas perusahaan untuk memproduksi produk yang sesuai dengan spesifikasi atau memenuhi kebutuhan konsumen. Strategi fleksibilitas didefinisikan sebagai kemampuan untuk merespon perubahan cepat dalam produk, jasa dan proses. Sedangkan strategi pengiriman didefinisikan sebagai keandalan dalam memenuhi jadwal pengiriman yang diminta dan dijanjikan, atau kecepatan dalam merespon pemesanan konsumen

\section{Kerangka Konsep Penelitian}

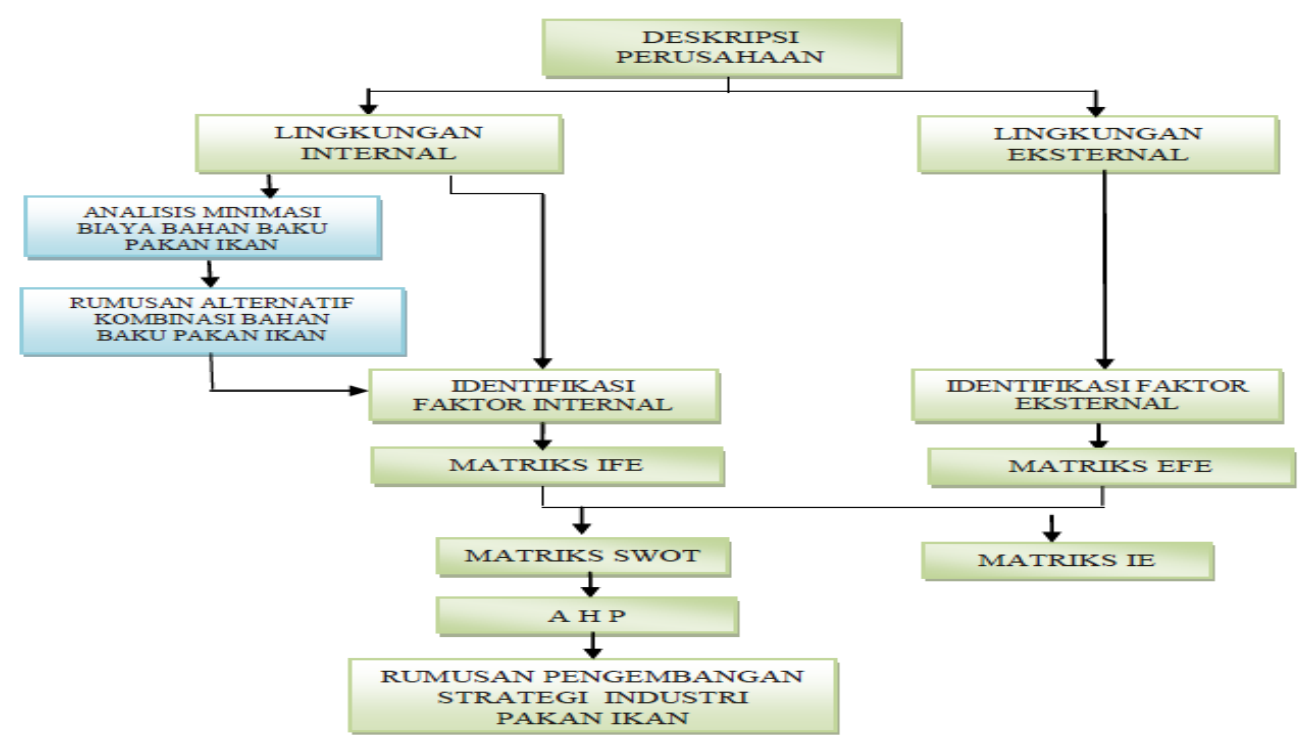

\section{METODE PENELITIAN}

Obyek penelitian ini adalah aktivitas bisnis CV. Babelan Agro Sejahtera (CV. BAS) di Kampung Kedaung Desa Kedung Jaya Kecamatan Babelan Kabupaten Bekasi. Data yang diperlukan untuk menyusun profil perusahaan dikumpulkan dengan cara wawancara dengan pengelola, pengamatan lapangan, dan penelusuran laporan keuangan perusahaan. Sedangkan untuk keperluan AHP, rsponden terdiri dari pengelola dan responden ahli agribisnis/agroindustri. Selanjutnya Data yang terkumpul dianalisis, dengan Analisis Deskriptif, Metode Simpleks, Analisis SWOT, dan Analytical Hierarchy Process.

\section{Analisis Deskriptif}

Analisis deskriptif bertujuan untuk mendeskripsikan profil perusahaan, lingkungan internal dan eksternal perusahaan berdasarkan wawancara, pengamatan, dan data sekunder.

\section{Metode Simpleks untuk Minimasi Bahan Baku Pakan Ikan}

Tahapan dalam analisis ini adalah formulasi persoalan, menyusun tabel bbservasi, formulasi model matematis, evaluasi dan perhitungan, dan rekomendasi. perhitungan dilakukan dengan menggunakan software POMforWINDOWS. 


\section{Analisis SWOT}

Analisa data internal dan eksternal yang menjadi faktor kunci dan terkait dengan manajemen operasi CV. BAS. Data tersebut dianalisis dengan matriks IFE, EFE, Matriks IE dan Matriks SWOT sebagai berikut :

1. Matrik IFE (Internal Factor Evaluation) Matrik IFE digunakan untuk mengetahui faktor-faktor internal yang berpengaruh terhadap perusahan dan terkait dengan kekuatan dan kelemahan yang dianggap paling dominan dalam pemilihan strategi. Data dan informasi aspek internal perusahaan dapat digali dari beberapa fungsional perusahaan, yaitu dari aspek operasi, pemasaran, keuangan, dan sumber daya manusia.

2. Matrik EFE (External Factor Evaluation) Matrik EFE digunakan untuk mengevaluasi faktor-faktor eksternal perusahaan. Data eksternal dikumpulkan untuk menganalisa hal-hal yang menyangkut persoalan

3. Matriks Internal-External (IE)

Matriks Internal-External(IE) merupakan salah satualatuntuk menyesuaikan kondisi internal dengan eksternal perusahaan dan mengembankan alternatif strategi yang tepat. Materiks IE ini bermanfaat untuk memposisikan berbagai divisi suatu organisasi kedalam matriks yang terdiri atas 9 sel. Matriks IE ini didasarkan pada informasi yang didapat pada tahap sebelumnya dengan menggunakan hasil evaluasi dari matriks IFE dan matriks EFE dimana untuk sumbu horizontal pada matrik IE ini adalah total skor dari matriks IFE, sedangkan untuk sumbu matriks vertikal adalah total skor dari matriks EFE.

\section{Matriks SWOT}

Matriks SWOT digunakan untuk mengembangkan alternatif strategi guna membantu dalam melakukan pencocokkan antar kekuatan dan peluang (strategi SO), kekuatan dan ancaman (strategi ST), peluang dan kelemahan (strategi WO) serta kelemahan dan ancaman (strategi WT).

\section{Analytical Hierarchy Process (AHP)}

Analitycal Hierarchy Process (AHP) merupakan salah satu teknik yang digunakan dalam pengambilan suatu keputusan pada sebuah hirarki fungsional dengan input utamanya adalah persepsi manusia. Dalam mempergunakan prinsip ini, AHP memasukkan baik aspek kualitatif maupun kuantitatif pikiran manusia,aspek kualitatif untuk mendefenisikan persoalan dan hirarkinya sedangkan aspek kuantitatif untuk mengekspresikan penilaian dan preferensi secara ringkas dan padat. (Saaty 1993)

Prinsip kerja AHP adalah penyederhanaan suatu persoalan kompleks yang tidak terstruktur, strategis, dan dinamik menjadi sebuah bagian-bagian dan tertata dalam suatu hierarki. Tingkat kepentingan setiap variabel diberi nilai numerik, secara subjektif tentang arti penting variabel tersebut dan secara relatif dibandingkan dengan variabel yang lain. Setelah itu, dari berbagai pertimbangan kemudian dilakukan sintesa untuk menetapkan variabel yang memiliki prioritas tinggi dan berperan untuk mempengaruhi hasil pada sistem tersebut. secara grafis persoalan keputusan AHP dapat dikonstruksikan sebagai diagram bertingkat (hierarki). AHP dimulai dengan goal atau sasaran lalu kriteria level pertama, subkriteria dan akhirnya alternatif.

\section{HASIL DAN PEMBAHAAN}

\section{Profil Perusahaan}

CV. Babelan Agro Sejahtera (CV. BAS) terletak di Kampung Kedaung Desa Kedung Jaya Kecamatan Babelan Kabupaten Bekasi dan didirikan pada tahun 2003. CV.BAS adalah salah satu dari sedikit usaha kecil produsen pakan ikan yang masih bertahan dan bahkan berkembang di tengah ketatnya persaingan pakan ikan yang umumnya didominasi Perusahaan Besar dengan jaringan distribusi kuat dan luas serta memberikan kemudahan dalam tempo pembayaran. Mahalnya harga pakan ikan produksi perusahaan besar sudah lama dikeluhkan petani ikan sebagai akibat masih tingginya ketergantungan kepada bahan baku impor terutama tepung ikan mendorong CV.BAS untuk memproduksi pakan ikan berbasis bahan baku produk sampingan agrbisnis terkait yang ada di Bekasi dan sekitarnya, dengan kualitas standar dan harga lebih murah.

Pakan ikan yang diproduksi dengan merek dagang Babelan Agro Sejahtera dipasarkan 
di daerah Bandung dan Cianjur, yakni petani ikan di Waduk Cirata dan Saguling. Sebagian lagi di sekitar Jabodetabek, dan mulai merintis agen di daerah Klaten Jawa Tengah.

Sedikit demi sedikit usaha ini berkembang dan telah mendapat kepercayaan dari Bank Mandiri sejak tahun 2006 sehingga mendapat kemudahan dalam mendapatkan kredit. Bahkan pada pertengahan 2010, pemilik usaha ini mendapat penghargaan dari Bank Mandiri sebagai wirausaha yang sukses dengan produk yang unik. Saat ini CV. BAS memproduksi pakan ikan rata-rata $600 \mathrm{~kg}$ per hari dengan kemampuan memproduksi hingga 1 ton per hari memiliki omset sekitar Rp.50 juta per bulan. Perusahaan yang dikelola oleh pemiliknya sendiri ini memiliki 5 karyawan yang merupakan pemuda putus sekolah.

\section{Minimasi Biaya Bahan Baku}

CV. BAS berupaya memproduksi pakan ikan dengan kualitas standar dan harga jual yang murah sebagai strateginya. Evaluasi formula bahan baku penyusun pakan ikan dilakukan agar standar kualitas pakan ikan terjaga dan biaya pengadaannya lebih kecil. Analisis minimasi biaya bahan baku dengan metode simpleks menghasilkan perbandingan formula bahan baku dan harga sebagai berikut

Tabel 1 Perbandingan formula dan harga pakan ikan sebelum dan sesudah minimasi

\begin{tabular}{|c|c|c|c|c|c|}
\hline \multirow{3}{*}{$\begin{array}{c}\text { Nama } \\
\text { Bahan Pakan }\end{array}$} & \multirow{3}{*}{$\begin{array}{c}\text { Harga } \\
\text { (Rp/ } \\
\text { kg) }\end{array}$} & \multicolumn{4}{|c|}{ Perbandingan komposisi dan harga } \\
\hline & & \multicolumn{2}{|c|}{ Sebelum Minimasi } & \multicolumn{2}{|c|}{ Setelah Minimasi } \\
\hline & & $\begin{array}{c}\text { Komposisi } \\
(\%)\end{array}$ & $\begin{array}{c}\text { harga } \\
(\mathrm{Rp})\end{array}$ & $\begin{array}{c}\text { Komposisi } \\
(\%)\end{array}$ & $\begin{array}{c}\text { Harga } \\
\text { (Rp) }\end{array}$ \\
\hline Tepung Ikan & 3500 & 25.00 & 875.00 & 39.00 & 1365.00 \\
\hline Bungkil sawit/kopra & 2300 & 16.00 & 368.00 & 25.00 & 575.00 \\
\hline Bungkil Kedelai & 3700 & 18.00 & 666.00 & 0.00 & 0.00 \\
\hline Tepung Susu & 4500 & 5.00 & 225.00 & 0.00 & 0.00 \\
\hline Dedak & 2100 & 35.00 & 735.00 & 35.00 & 735.00 \\
\hline Vitamin & 12000 & 0.50 & 60.00 & 0.50 & 60.00 \\
\hline Minyak ikan & 7000 & 0.50 & 35.00 & 0.50 & 35.00 \\
\hline Jumlah & & 100 & 2964.00 & 100.00 & 2770.00 \\
\hline
\end{tabular}

Catatan : bungkil sawit dan bungkil kopra dipakai salah satu, tergantung ketersediaan bahan.

Reformulasi pakan ikan menghasilkan perubahan komposisi penggunaan bahan baku, yaitu komposisi awal adalah tepung ikan, bungkil sawit/bungkil kopra, bungkil kedelai, tepung susu, dedak, vitamin, dan minyak ikan masing-masing dengan proporsi $25 \%, 16 \%, 18 \%, 5 \%, 35 \%, 0.5 \%$, dan $0.5 \%$ memerlukan biaya bahan pakan ikan sebesar Rp. 2964,00/kg, dan komposisi setelah minimasi adalah tepung ikan, bungkil sawit/ bungkil kopra, dedak, vitamin, dan minyak ikan masing-masing dengan proporsi $39 \%, 25$ $\%, 35 \%, 0.5 \%$, dan $0.5 \%$ memerlukan biaya bahan pakan ikan sebesar Rp. 2770,00/kg.

Hasil analisis ini menunjukkan bahwa dengan tetap mempertahankan mutu pakan ikan, formula dapat diubah dan harga bahan baku pakan ikan dapat ditekan. Hal ini menunjukkan bahwa CV. BAS tetap dapat mempertahankan harga, bahkan dapat menurunkan harga. Strategi tersebut perlu didukung dengan upaya mencari alternatif bahan bakulainnya disekitar lokasiperusahaan. Manajemen pasokan perlu dibenahi untuk antisipasi resiko kekurangan bahan baku dan mutu bahan baku yang rendah.

\section{Analaiis SWOT}

\section{Analisis Matriks IFE}

Faktor-faktor yang menyusun matriks IFE adalah faktor-faktor internal yang terdiri dari kekuatan dan kelemahan. Faktor kekuatan CV. BAS terdiri dari : Harga Produk Kompetitif dan Bahan baku berbasis lokal dan produk sampingan. Sedangkan faktor kelemahan terdiri dari : kapasitas produksi terbatas dan jaringan distribusi terbatas. Hasil analisis matriks IFE dapat dilihat pada Tabel 2. 
Tabel 2 Hasil analisis matriks IFE

\begin{tabular}{lccc}
\hline \multicolumn{1}{c}{ Faktor Internal } & $\begin{array}{c}\text { Bobot } \\
(\mathbf{A})\end{array}$ & $\begin{array}{c}\text { Rating } \\
(\mathbf{B})\end{array}$ & $\begin{array}{c}\text { Skor } \\
(\mathbf{A x B})\end{array}$ \\
\hline KEKUATAN & & & \\
1.Harga Jual Produk Kompetitif & $\mathbf{0 , 3}$ & $\mathbf{4}$ & $\mathbf{1 . 2 0}$ \\
2.Bahan Baku berbasis lokal dan produk sampingan & 0,25 & 4 & 1.00 \\
KELEMAHAN & & & \\
1.Kapasitas Produksi Terbatas & 0,20 & 2 & 0,40 \\
2.Jaringan Distribusi Terbatas & $\mathbf{0 , 2 5}$ & $\mathbf{2}$ & $\mathbf{0 , 5 0}$ \\
$\quad$ TOTAL & $\mathbf{1 , 0 0}$ & $\mathbf{1 2}$ & $\mathbf{3 . 1 0}$ \\
\hline
\end{tabular}

Berdasarkan hasil perhitungan Matriks IFE pada Tabel 14, bahwa factor harga produk kompetitif (1.20) lebih kuat dibanding Bahan baku berbasis lokal dan produk sampingan (1.00). Tanpa harga produk yang kompetitif, pakan ikan produksi CV.BAS tidak akan mampu memiliki daya saing. Bila harganya sama dapat dipastikan petani ikan akan memilih pakan ikan produksi perusahaan besar karena lebih dipercaya.

Pada faktor kelemahan, jaringan distribusi yang terbatas (0.50) lebih perlu mendapat perhatian dibanding kapasitas produksi terbatas $(0.40)$. Hal ini dikarenakan untuk meningkatkan kapasitas perlu didahului dengan jaminan pasar. Jaminan pasar dapat terwujud bila jaringan distribusi diperbaiki.

Bobot skor total matriks IFE sebesar 3.10 menunjukkan bahwa CV. BAS memiliki posisi internal yang kuat, artinya perusahaan telah mampu menggunakan kekuatan yang dimiliki dan mengatasi kelemahan.

\section{Analisis Matriks EFE}

Matrik EFE berguna untuk mengetahui sebererapa besar faktor-faktor eksternal yang mempengaruhi usaha CV.BAS. Faktor eksternal terdiri dari peluang dan ancaman. Peluang $\mathrm{CV}$. BAS adalah pangsa pasar pakan ikan murah bermutu masih luas dan kerjasama distribusi dengan koperasi dan agen. Sedangkan ancamannya adalah Jaringan distribusi pesaing luas dan ada kemudahan pembayaran dan pasokan bahan baku utama belum stabil. Hasil analisis matriks EFE dapat dilihat pada Tabel 3.

Berdasarkan hasil perhitungan Matriks EFE pada Tabel. Dapat dilihat bahwa pada faktor peluang, potensi pasar pakan ikan murah bermutu masih besar (0.75) lebih tinggi skornya dibanding kerjasama distribusi dengan koperasi dan agen (0.60). Peluang pasar pakan ikan murah bermutu menjadi daya tarik sangat penting bagi CV. BAS ketika mulai merintis usahanya dan ketika akan mengembangkannya.

Tabel 3. Hasil analisis matriks EFE

\begin{tabular}{lccc}
\hline \multicolumn{1}{c}{ Faktor Eksternal } & $\begin{array}{c}\text { Bobot } \\
(\mathbf{A})\end{array}$ & $\begin{array}{c}\text { Rating } \\
(\mathbf{B})\end{array}$ & $\begin{array}{c}\text { Skor } \\
(\mathbf{A x B})\end{array}$ \\
\hline PELUANG & & & \\
1. Potensi pasar pakan ikan murah bermutu masih besar & 0,25 & 3 & 0,75 \\
2. Kerjasama distribusi dengan koperasi dan agen & 0,20 & 3 & 0,60 \\
ANCAMAN & & & \\
$\begin{array}{l}\text { 1. Jaringan distribusi pesaing luas dan ada kemudahan } \\
\text { pembayaran }\end{array}$ & 0,25 & 2 & 0,50 \\
$\begin{array}{l}\text { 2. Pasokan bahan baku Utama belum stabil } \quad \text { TOTAL } \\
\quad\end{array}$ & 0,30 & 2 & 0.60 \\
\end{tabular}

Pada faktor ancaman, pasokan bahan baku utama belum stabil (0.60) menjadi ancaman yang lebih serius dibanding jaringan distribusi pesaing luas dan ada kemudahan pembayaran $(0.5)$ dan. Bobot skor total diperoleh adalah 2,45. Hal ini menunjukkan bahwa CV. BAS memiliki posisi eksternal rata-rata (sedang), artinya bahwa perusahaan ini memiliki kemampuan merespon 
tergolong cukup dan belum menggunakan secara optimal peluang-peluang yang ada untuk mengatasi ancaman.

\section{Analisis Matriks IE}

Matriks IE merupakan matrik yang menggabungkan bobot skor Matriks IFE dan Matriks EFE untuk melihat posisi sel CV. BAS. Jika posisi sel telah diketahui, maka diketahui pula strategi apa yang harus dilakukan oleh perusahaan. Perhitungan Matriks IFE mununjukkan bahwa bobot skornya adalah
3.10 dan dari Matriks EFE didapatkan bobot skor 2,45 . Hasil pemetaan matriks IE dapat dilihat pada Gambar 1.

CV. BAS menempati posisi sel IV, berarti menggambarkan bahwa posisi $\mathrm{CV}$. BAS berada pada posisi grow and build (tumbuh dan membangun). Menurut David (2011) strategi yang tepat bagi usaha yang berada di sel ini adalah integrasi ke belakang, integrasi ke depan, atau integrasi horizontal, penetrasi pasar, pengembangan pasar, dan pengembangan produk.

\section{Skor Bobot Total IFE}

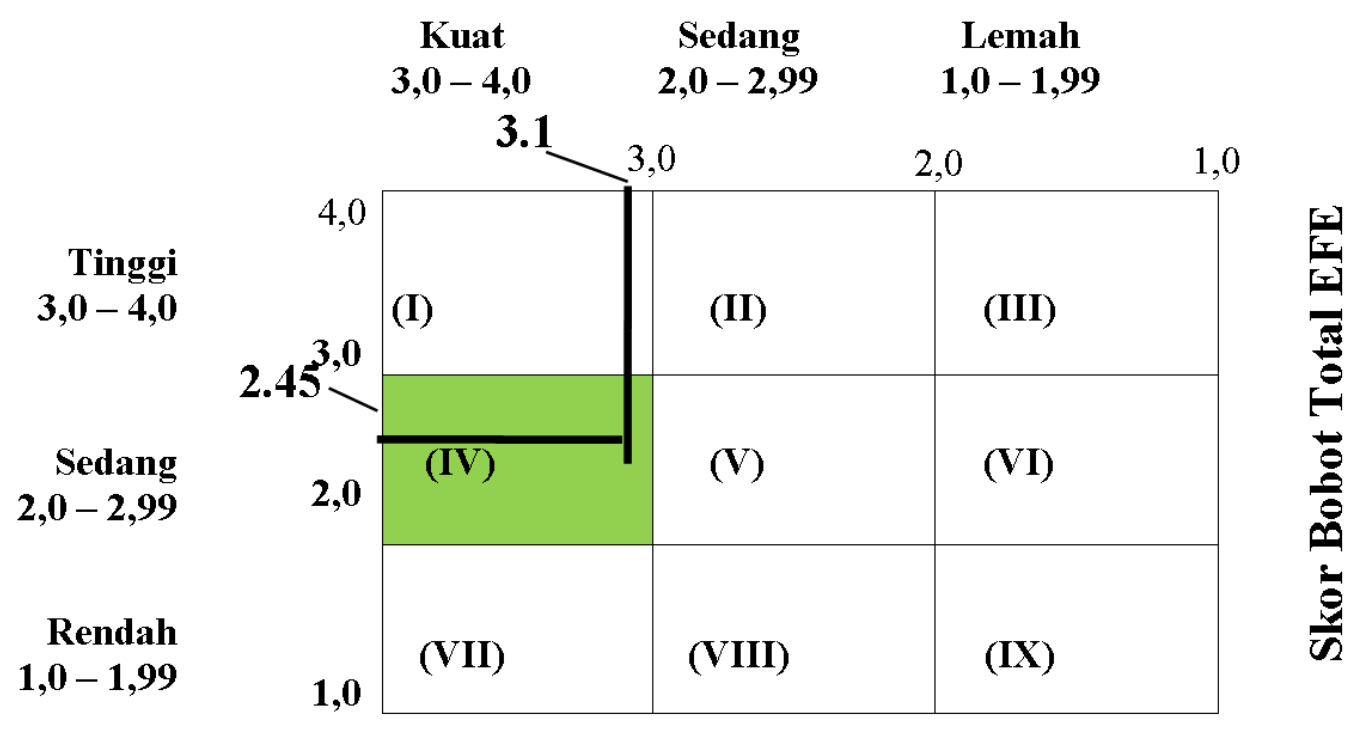

Gambar 1. Hasil matriks IE

\section{Analisis Matriks SWOT}

Setelah dilakukan analisis matriks IFE dan EFE yang menghasilkan matriks IE - kemudian disusun matriks SWOT untuk merumuskan strategi-strategi berdasarkan faktor-faktor internal dan eksternal yang telah teridentifikasi dari CV. BAS. Perumusan strategi operasi CV.BAS tercantum pada Tabel 4 .

Tabel 4 Matriks strategi hasil analisis SWOT

\begin{tabular}{|c|c|c|}
\hline Ekst & \begin{tabular}{ll}
\multicolumn{1}{c}{ Peluang } \\
1. \\
Pangsa pasar pakan ikan \\
murah bermutu masih luas \\
2. Kerjasama distribusi dengan \\
koperasi dan agen
\end{tabular} & \begin{tabular}{ll}
\multicolumn{2}{c}{ Ancaman } \\
1. Jaringan Distribusi Pesaing luas \\
dan ada kemudahan pembayaran \\
2. Pasokan Bahan Baku Utama belum \\
stabil
\end{tabular} \\
\hline Kekuatan & & \\
\hline $\begin{array}{l}\text { 1. Harga Jual Produk Kompetitif } \\
\text { 2. Bahan Baku berbasis lokal } \\
\text { dan produk sampingan }\end{array}$ & $\begin{array}{ll}\text { - } & \text { Mempertahankan harga jual } \\
& (\mathrm{S} 1, \mathrm{O} 1, \mathrm{O} 2) \\
\text { - } & \text { Peningkatan kapasitas } \\
& \text { produksi }(\mathrm{S} 2, \mathrm{O} 1, \mathrm{O} 2)\end{array}$ & $\begin{array}{l}\text { - Meningkatkan daya saing produk } \\
\text { berbasis harga murah (S1,T1) } \\
\text { - Meningkatkan Stabilitas Pa-sokan } \\
\text { Bahan Baku (S2,T1,T2 }\end{array}$ \\
\hline Kelemahan & & \\
\hline $\begin{array}{l}\text { 1. Kapasitas Produksi Terbatas } \\
\text { 2. Jaringan Distribusi Terbatas }\end{array}$ & $\begin{array}{ll}\text { - } & \text { Penambahan Mesin Produksi } \\
& (\mathrm{W} 1, \mathrm{O} 1) \\
\text { - } & \text { Realisasi Kerjasama } \\
& \text { Distribusi }(\mathrm{W} 2, \mathrm{O} 1, \mathrm{O} 2) \\
\end{array}$ & $\begin{array}{ll}- & \text { Pengembangan SCM } \\
& (\mathrm{W} 1, \mathrm{~W} 2, \mathrm{~T} 1, \mathrm{~T} 2) \\
- & \text { Mengembangkan jaringan distribusi } \\
& (\mathrm{W} 2, \mathrm{~T} 1) \\
\end{array}$ \\
\hline
\end{tabular}


Matriks strategi hasil analisis SWOT menunjukkan bahwa strategi yang yang dapat dirumuskan sebagai hasil mempertimbangkan Kekuatan-Peluang, Kekuatan-Ancaman, Kelemahan-Peluang, dan KelemahanAncaman adalah :

a. Mempertahankan harga jual $(\mathrm{S} 1, \mathrm{O} 1, \mathrm{O} 2)$

b. Peningkatan kapasitas produksi (S2,O1,O2)

c. Promosi berbasis harga murah $(\mathrm{S} 1, \mathrm{~T} 1)$

d. Meningkatkan Stabilitas Pasokan Bahan Baku (S2,T2)

e. Penambahan Mesin Produksi (W1, O1)

f. Realisasi Kerjasama Distribusi (W2,O1,O2)

g. Pengembangan SCM (W1,W2,T1,T2)

h. Mengembangkan jaringan distribusi (W2,T1)

Berdasarkan cakupan dari masingmasing strategi dan kemudian didiskusikan dengan pengelola $\mathrm{CV}$. BAS, maka 8 strategi tersebut dapat diringkas menjadi 3 strategi. Strategi 1 digabung dengan strategi 3. Strategi 2 dan 5 digabungkan. Strategi 4, 6, 7, dan 8 digabungkan. Dengan demikian maka, strategi yang dapat dirumuskan menjadi 3, yaitu (1) mempertahankan harga jual (2) peningkatan kapasitas produksi, dan (3) pengembangan SCM.

\section{a. Mempertahankan harga jual,}

Mempertahankan harga jual adalah strategi yang perlu dilakukan CV. BAS dalam menggunakan kekuatan untuk memanfaatkan peluang dan mengatasi ancaman. Harga jual produk kompetitif (S1) harus dimanfaatkan untuk meraih pangsa pasar pakan ikan murah bermutu yang masih luas (O1) dan menghadapi ancaman jaringan distribusi pesaing yang luas dan memberikan kemudahan tempo pembayaran (T1).

\section{b. Peningkatan Kapasitas Produksi}

Peningkatan kapasitas produksi adalah strategi ang harus dijalankan oleh CV. BAS dalam rangka menggunakan kekuatan untuk meraih peluang, meminimalkan kelemahan untuk memanfaatkan peluang dan menghadapi ancaman. Bahan baku lokal dan berbasis produk sampingan dengan kualitas standar dan harga murah harus digunakan untuk memacu peningkatan kapasitas produksi untuk meraih pangsa pasar pakan ikan murah berkualitas yang masih terbuka (O1) dan menjalin kerjasama dengan koperasi dan agen (O2). Selanjutnya Kapasitas produksi terbatas (W1) harus ditingkatkan untuk memanfaatkan pasar pakan ikan murah berkualitas yang masih terbuka (O1).

\section{c. Pengembangan Suplly Chain Management (SCM) \\ Pengembangan SCM adalah strategi yang} harus dilakukan dalam rangka menggunakan kekuatan untuk memanfaatkan peluang dan menghadapi ancaman, serta meminimalkan kelemahan untuk memanfaatkan peluang dan menghadapi ancaman. Melalui pengembangan SCM, Bahan Baku berbasis lokal dan produk sampingan (S2) dapat digunakan untuk menghadapi ancaman pasokan bahan baku utama belum stabil (T2). Kapasitas produksi terbatas (W1) harus ditingkatkan dalam kerangka pengembangan SCM untuk menghadapi Jaringan Distribusi Pesaing luas dan ada kemudahan pembayaran (T1) dan pasokan bahan baku yang belum stabil (T2). Melalui pengembangan SCM Jaringan Distribusi yang Terbatas (W2) dapat diatasi agar pemasaran produk lancar dan perusahaan mampu mengatasi ancaman pasokan bahan baku yang belum stabil (T2).

\section{Prioritas Strategi Operasi CV. BAS}

\section{Penyusunan Konstruksi AHP}

Konstruksi AHP dalam perumusan strategi pengembangan $\mathrm{CV}$, BAS disusun menjadi 3 (tiga) level hirarki, yaitu : (1) Level pertama ditetapkan sebagai tujuan yang akan dicapai, yaitu strategi operasi yang optimal, (2) Level kedua kriteria-kriteria yang diperlukan untuk mencapai tujuan, yaitu biaya, kualitas, pengiriman, dan fleksibilitas, dan (3) alternatif-alternatif yang akan dievaluasi di bawah kriteria, yaitu mempertahankan harga, dan peningkatan kapasitas produksi, dan pengembangan SCM . Struktur hirarki pengembangan strategi operasi $\mathrm{CV}$. BAS dapat dilihat pada gambar berikut. 


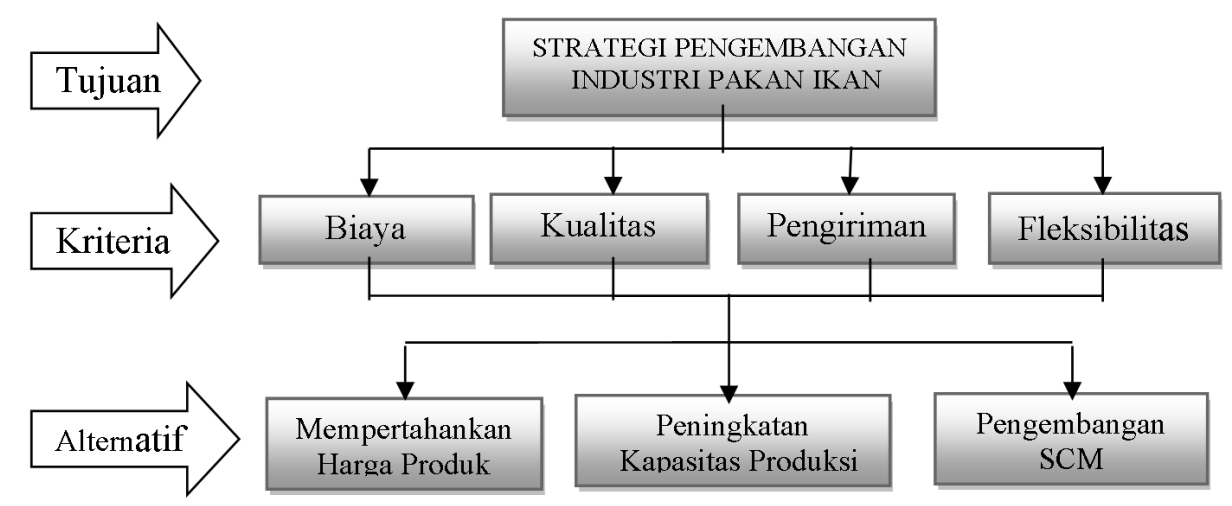

Gambar 2 Konstruksi analisis hierarki proses

Strategi pengembangan industri pakan ikan dirumuskan sebagai tujuan sebagaimana tujuan dari riset ini adalah untuk merumuskan strategi pengembangan industri pakan ikan untuk meningkatkan daya saing produk.

Kriteria sebanyak 4 (empat) merupakan prioritas kompetitif dalam strategi operasi meliputi biaya(cost), kualitas (quality), fleksibilitas (flexibility), dan pengiriman (delivery). Keempat dimensi strategi tersebut bukanlah strategi yang saling meniadakan satu sama lain, tetapi merupakan satu kesatuan yang terpadu dan saling memperkuat.

Alternatif yang terdiri dari 3 (tiga) strategi, yaitu mempertahankan harga, dan peningkatan kapasitas produksi, dan pengembangan SCM merupakan hasil dari analisis SWOT.

\section{Prioritas Kriteria dan Strategi}

Berdasarkan data kuisioner yang kemudian diolah dengan software super decision, hasil dari AHP dapat disajikan pada gambar 3 .

\section{a. Prioritas Kriteria Strategi Operasi CV. BAS}

Sebagaimana terlihat pada Gambar 5, bahwa dari 4 (empat) kriteria yang harus diperhatikan dalam menjalankan strategi operasi, masing-masing memiliki bobot yang berbeda dengan urutan prioritas, yaitu kualitas (0.473), pengiriman (0.230), fleksibilitas (0.184), dan biaya (0.113). Strategi biaya adalah produksi dan distribusi sebuah produk dengan biaya terendah dan sumber daya tersisa (waste resources) yang minimum. Strategi ini mencerminkan prioritas perusahaan pada efisiensi biaya agar mampu berkompetisi berbasis pada biaya. Strategi kualitas didefinisikan sebagai aktivitas perusahaan untuk memproduksi produk yang sesuai dengan spesifikasi atau memenuhi kebutuhan konsumen. Strategi fleksibilitas didefinisikan sebagai kemampuan untuk merespon perubahan cepat dalam produk, jasa dan proses. Sedangkan strategi pengiriman didefinisikan sebagai keandalan dalam memenuhi jadwal pengiriman yang diminta dan dijanjikan, atau kecepatan dalam merespon pemesanan konsumen

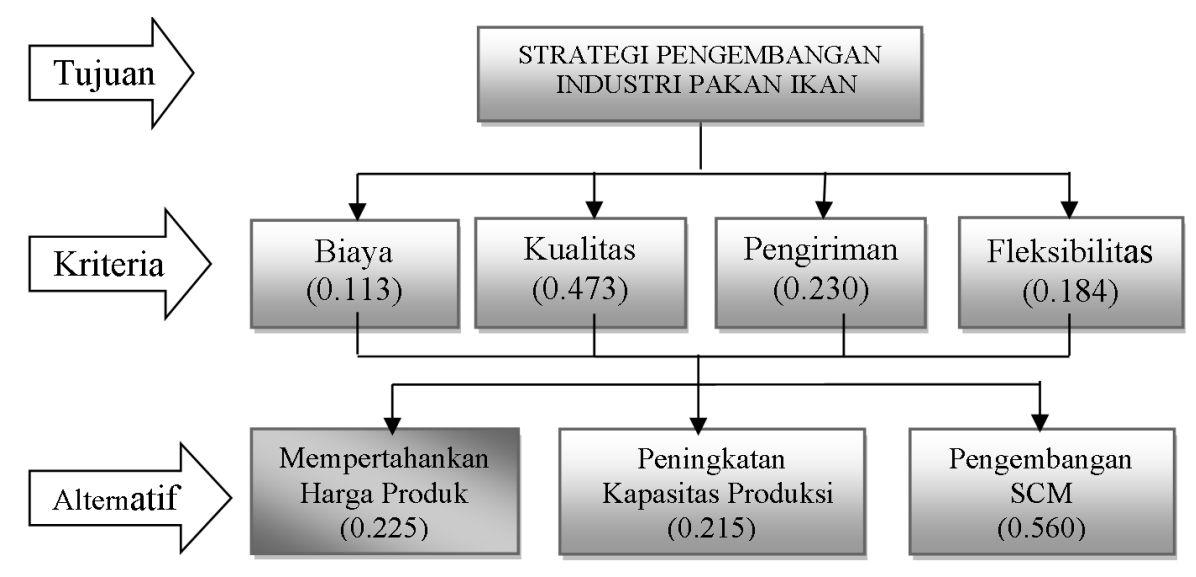

Gambar 3 Hasil analisis hierarki proses 
Kriteria kualitas dengan bobot terbesar menunjukkan bahwa kualitas pakan ikan produksi CV. BAS merupakan hal yang harus mendapat perhatian utama dalam persaingan, apalagi bersaing dengan produk dari perusahaan besar yang biasanya lebih dipercaya standar kualitasnya dibanding usaha kecil. Kriteria ini menuntut perusahaan harus memproduksi produk yang sesuai dengan spesifikasi yang dibutuhkan konsumen, yaitu kandungan protein tidak kurang dari $25 \%$, warna yang lazim, dan bau yang lazim.

Kriteria kedua adalah pengiriman. CV. BAS harus berupaya semaksimal mungkin untuk mengirim pakan ikan sesuai waktu yang diminta petani ikan atau dijanjikan $\mathrm{CV}$. BAS secara tepat waktu. Hal ini penting untuk menjaga kualitas layanan kepada pelanggan. Kriteria fleksibilitas terkait dengan kemampuan merespon perubahan dalam produk dan proses. Pengiriman dan fleksibilitas sering menjadi 2 kriteria dalam strategi operasi yang harus dperhatikan CV. BAS dalam waktu bersamaan ketika merespon pesanan konsumen yang menuntut jumlah lebih besar dari kapasitas standar dan waktu penyelesaian dan pengiriman yang lebih cepat. CV. BAS perlu memperbaiki mekanisme kerja lembur untuk merespon pesanan yang melebihi kapasitas normal. Sedangkan untuk pengiriman CV. BAS perlu meningkatkan kemampuan mengirim dengan alat transportasi yang ada.

Biaya sebagai kriteria dengan prioritas terakhir yang harus dipertimbangkan dalam strategi operasi CV. BAS. Aktivitas yang menonjol untuk mewujudkan kriteria ini adalah pada pengadaan bahan baku yang berbasis lokal dan produk sampingan perikanan tangkap dan agroindustri. CV. BAS berupaya semaksimal mungkin untuk mendapatkan bahan baku berkualitas dengan harga murah karena hal ini menjadi senjata untuk bersaing. Tapi sisi lain untuk memenuhi kriteria kualitas yang sesuai, pengiriman yang cepat, dan pesanan yang fleksibel, CV. BAS kadang-kadang harus menambah biaya.

\section{b. Prioritas Strategi Pengembangan $\mathrm{CV}$. BAS.}

Tiga aternatif strategi pengembangan $\mathrm{CV}$. BAS masing masing memiliki bobot yang berbeda seperti terlihat pada Gambar 3. Untuk mengimplementasikannya, prioritas strategi operasi CV. BAS disesuaikan dengan skornya dengan urutan sebagai berikut: pengembangan SCM (0.560), mempertahankan harga (0.225) dan peningkatan kapasistas produksi (0.215). Implementasi 3 (tiga) strategi operasi tersebut adalah sebagai berikut :

\section{1) Pengembangan SCM}

Pengembangan SCM adalah strategi yang relevan dengan lingkungan internal mencakup kekuatan dan kelemahan, serta lingkungan eksternal perusahaan mencakup peluang dan ancaman. Hasil analisis matriks IE dalam analisis SWOT, dimana bidang operasi CV. BAS menempati posisi sel IV, berarti menggambarkan growth and build (tumbuh dan membangun). Menurut David (2011) strategi yang tepat bagi usaha yang berada di sel ini adalah integrasi ke belakang, integrasi ke depan, atau integrasi horizontal, penetrasi pasar, pengembangan pasar, dan pengembangan produk. Pemberian prioritas pertama terhadap pengembangan SCM bagi CV. BAS dalam menerapkan strategi operasi yang optimal untuk meningkatkan daya saing produknya ini sejalan dengan hasil analisis matriks IE di atas.

Rekomendasi analisis minimasi biaya produksi bahwa reformulasi pakan ikan dapat dilakukan dan mampu menurunkan biaya pembelian bahan baku memerlukan dukungan pasokan bahan baku yang lebih stabil. Upaya menstabilkan pasokan bahan baku merupakan bagian sangat penting dalam pengembangan SCM.

Berdasarkan uraian di atas ada beberapa hal yang perlu dilakukan dalam melaksanakan strategi pengembangan SCM, yaitu :

- Meningkatkan kualitas manajemen pasokan bahan baku untuk menjamin kuantitas, kualitas, dan kontinuitas pasokan.

- Perbaikan perencanaan persediaan bahan baku, untuk mewujudkan tingkat persediaan bahan baku yang optimal sehingga meminimalkan resiko kekurangan dan kelebihan bahan baku.

- Menambah mesin cetak pakan ikan dan memperbaiki pemeliharaannya untuk menghindari tertundanya waktu proses 
sehingga terhindar dari resiko kerusakan pakan dan tertundanya waktu pemenuhan pesanan.

- Membangun jaringan distribusi dengan segera menindaklanjuti permintaan kerjasama yang diajukan oleh koperasi petani ikan dan agen, serta membuka jaringan lainnya untuk pengembangan pasar.

- Mengindentifikasi resiko-resiko SCM meliputi pengadaan bahan baku, penanganan bahan selama berada di pabrik, dan distribusi produk serta merumuskan langkah antisipasinya.

\section{2) Mempertahankan harga produk}

Sampai saat ini pasar pakan ikan masih didominasi perusahaan besar dengan harga relative mahal. Dengan demikian mempertahankan harga produk agar mampu berkompetisi di pasar adalah pilihan strategi yang harus dilakukan. Berdasarkan analisis minimasi biaya bahan baku, strategi ini masih dapat dipertahankan, bahkan bila diperlukan harga masih mungkin diturunkan. Implementasi strategi ini relative mudah dilakukan karena selama ini CV. BAS telah berkomitmen untuk menjual produk dibawah rata-rata harga pasaran.

Mengacu kepada rekomendasi David (2011), strategi mempertahankan harga produk ini harus didukung dengan integrasi ke depan, dengan memperbaiki manajemen pasokan agar kuantitas, kualitas, dan kontinuitas bahan baku terjamin. Kaitannya dengan distribusi produk, perusahaan perlu melakukan integrasi ke belakang dan pengembangani pasar. Petani ikan yang masih sering mengeluhkan harga pakan ikan yang cenderung semakin mahal sebagai bukti masih terbukanya pasar perlu dijadikan sasaran promosi agar lebih mengenal pakan ikan murah bermutu yang diproduksi CV. BAS.

\section{3) Peningkatan Kapasitas Produksi}

Bagi CV. BAS, peningkatan kapasitas produksi dapat dilakukan bila ada jaminan pasar dan jaminan pasokan bahan baku yang menjadi bagian utama dari strategi pengembangan SCM. Bila hal itu telah dilakukan maka dalam jangka pendek, peningkatan kapasitas produksi dapat dilakukan dengan meningkatkan produksi sampai dengan kemampuan optimal yang bisa dicapai yaitu 1 ton per hari. Bila ini dapat dilakukan, maka CV. BAS akan dapat meningkatkan kapasitas produksinya minimal 40 persen. Dalam jangka menengah CV. BAS dapat meningkatkan kapasitas produksi dengan menambah jumlah mesin produksi sekaligus mengoptimalkan ruangan pabrik. Dalam jangka panjang, peningkatan kapasitas produksi memerlukan perluasan pabrik. Hal ini masih dimungkinkan mengingat luas bangunan sekitar 32 persen dari total luas lahan.

Prioritas strategi pengembangan tersebut nampak cukup realistis. Pengembangan SCM mendapat prioritas pertama karena menjadi syarat utama dalam melakukan peningkatan kapasitas produksi yang mendapat prioritas ketiga. Sedangkan mempertahankan harga jual produk yang mendapat prioritas kedua merupakan persyaratan yang harus dipenuhi dalam strategi operasi untuk meningkatkan daya saing.

Impementasi ketiga macam strategi operasi tersebut harus mempertimbangkan empat kriteria, dengan urutan prioritas adalah : (1) kualitas, (2) pengiriman, (3) fleksibilitas, dan (4) biaya.

\section{Implikasi Penelitian}

Penelitian ini menggunakan 3 alat analisis, yaitu analisis minimasi, analisis SWOT, dan AHP. Hasil dari penelitian ini adalah reformulasi pakan ikan dengan biaya yang lebih kecil, pemetaan bidang operasi CV. BAS ke dalam sel IV matriks IE, 3 rumusan strategi operasi hasil matriks SWOT, dan penyusunan prioritas strategi yang mempertimbangkan prioritas kriteria hasil AHP. Implikasi teoritis dalam penelitian ini adalah :

1. Analisis minimasi dengan metode simpleks sebagai salah satu alat analisis dalam program linier dalam formulasi pakan ikan terbukti mampu menghasilkan formulasi pakan ikan baru dengan kualitas yang sama atau lebih baik dan dengan biaya yang lebih kecil bila dibandingkan dengan metode yang dipakai oleh perusahaan, yaitu metode square pearson. Hal sesuai dengan kelebihan yang dimiliki program linier, yaitu kemampuan menyusun formulasi pakan ikan dengan jumlah bahan baku 
yang lebih banyak dan biaya minimal.

2. Penggunaan program linier dalam identifikasi faktor internal dalam analisis SWOT dilakukan sebagai upaya memperkuat informasi, sehingga analisis SWOT tidak hanya berdasarkan hasil identifikasi berbasis analisis kualitatif, tapi juga analisis kuantitatif. Penggunaan analisis kuantitatif dalam analisis SWOT sejalan dengan riset strategi operasi yang dilakukan, terutama dikaitkan dengan fungsi-fungsi dasar manajemen operasi seperti fungsi kapasitas, fungsi persediaan, dan fungsi kualitas.

3. Analisis SWOT yang digunakan dalam penelitian ini dapat memetakan CV. BAS pada posisi grow and build (tumbuh dan membangun). Selanjutnya dari analisis SWOT dapat disusun matriks strategi yang menghasilkan 8 strategi, yaitu : (1) Mempertahankan harga jual, (2) Peningkatan kapasitas produksi, (3) Promosi berbasis harga murah, (4) Meningkatkan Stabilitas Pasokan Bahan Baku, (5) Penambahan Mesin Produksi (6) Realisasi Kerjasama Distribusi, (7) Pengembangan SCM, (8) Mengembangkan jaringan distribusi

4. Penggunaan SWOT dan AHP dalam riset ini memiliki dua makna, pertama rumusan strategi dalam analisis SWOT dapat dipakai sebagai pertimbangan dalam menyusun konstruksi model AHP, dimana dalam penelitian ini untuk memudahkan implementasi AHP, 8 strategi hasil matriks SWOT di ringkas menjadi 3 strategi. Kedua, dalam rumusan strategi sebagai output dari analisis SWOT, perlu prioritas dalam implementasinya. Penentuan prioritas ini dilakukan dengan AHP.

Implikasi manajerial dari penelitian ini bagi pengelola CV. BAS adalah :

1. Reformulasi pakan ikan yang mengubah proporsi penggunaan bahan baku pakan yang dapat mengurangi biaya bahan baku meneguhkan strategi CV. BAS untuk menjual produk dengan harga di bawah rata-rata harga pasar. Hasil ini perlu ditindak lanjuti dengan perbaikan manajemen pasokan bahan baku agar kuantitas, kualitas, dan kontinuitas pasokan terjamin.

2. Posisi CV. BAS yang berada pada sel IV yang berarti tumbuh dan membangun perlu ditindaklanjuti oleh CV. BAS agar menerapkan strategi integrasi ke belakang, integrasi ke depan, atau integrasi horizontal, penetrasi pasar, pengembangan pasar, dan pengembangan produk.

3. Tiga rumusan strategi yang dihasilkan dari matriks SWOT, yakni mempertahankan harga jual produk, peningkatan kapasitas produksi, dan pengembangan SCM perlu diimplementasikan agar perusahaan mampu menggunakan kekuatan dan meminimalkan kelemahan guna memanfaatkan peluang dan mampu menghadapi ancaman.

4. Rumusan prioritas strategi dan prioritas kriteria operasi hasil AHP memberikan panduan kepada perusahaan agar strategi operasi yang terlebih dahulu diimplementasikan adalah pengembangan SCM. Selanjutnya dengan tetap mempertahankan harga jual produk, perusahaan mulai melakukan peningkatan kapasitas produksi. Dengan demikian peningkatan kapasitas produksi berbasis SCM yang berkualitas dan harga jual produk yang tetap dipertahankan dapat dilakukan sebagai bekal untuk melakukan penetrasi pasar dan pengembangan pasar, serta pengembangan produk.

Implikasi manajerial dari penelitian ini bagi pengambil kebijakan adalah bahwa mahalnya harga pakan ikan produksi perusahaan besar sudah lama dikeluhkan petani ikan sebagai akibat masih tingginya ketergantungan kepada bahan baku impor terutama tepung ikan dapat diatasi antara lain dengan mengeluarkan kebijakan yang mampu secara efektif mendorong berkembangnya industri kecil pakan ikan berbasis produk sampingan agribisnis. Kebijakan tersebut hendaknya dapat secaa konkrit mengatasi permasalahan industri kecil, yaitu masalah rendahnya kemampuan manajerial, teknis produksi, akses pasar, dan akses modal. Kebijakan tersebut dapat menjadi bagian penting sari kebijakan besar untuk 
mengantarkan Indonesia bisa swasembada pakan ikan mandiri agar pembudidaya ikan bisa lebih sejahtera.

\section{PENUTUP}

\section{Simpulan}

1. Reformulasi pakan ikan menghasilkan perubahan komposisi penggunaan bahan baku, yaitu komposisi awal adalah tepung ikan, bungkil sawit/bungkil kopra, bungkil kedelai, tepung susu, dedak, vitamin, dan minyak ikan masing-masing dengan proporsi $25 \%, 16 \%, 18 \%, 5 \%$, $35 \%, 0.5 \%$, dan $0.5 \%$ memerlukan biaya bahan pakan ikan sebesar Rp. 2964,00/kg, dan komposisi setelah minimasi adalah tepung ikan, bungkil sawit/bungkil kopra, dedak, vitamin, dan minyak ikan masing-masing dengan proporsi $39 \%, 25 \%, 35 \%, 0.5 \%$, dan $0.5 \%$ memerlukan biaya bahan pakan ikan sebesar Rp. 2770,00/kg. Hasil ini menunjukkan bahwa strategi penjualan produk dengan harga di bawah rata-rata harga pasar masih dapat dipertahankan..

2. CV. BAS berada pada sel IV matriks Internal Eksternal. berarti menggambarkan growth and build (tumbuh dan membangun) yang memberikan panduan kepada perusahan untuk melakukan strategi integrasi ke belakang, integrasi ke depan, atau integrasi horizontal, penetrasi pasar, pengembangan pasar, dan pengembangan produk

3. Matriks SWOT menghasilkan 3 rumusan strategi operasi, yaitu mempertahankan harga jual produk, peningkatan kapasitas produksi , dan pengembangan SCM

4. Hasil AHP memberikan urutan prioritas implementasi strategi : pengembangan SCM (0.560), mempertahankan harga
(0.225), dan peningkatan kapasistas produksi (0.215). Implementasi strategi tersebut harus memperhatikan 4 kriteria dengan urutan prioritas : Kualitas (0.473), Pengiriman (0.230), Fleksibilitas (0.180), dan Biaya (0.113),

\section{Saran}

1. Pasokan bahan baku utama pakan ikan yang belum stabil dan jaringan distribusi yang terbatas yang selama ini menjadi masalah dalam pengembangan usaha perlu segera diatasi sebagaimana telah diuraikan dalam implikasi manajerial. Hasil penelitian ini dapat dijadikan masukan oleh CV. BAS agar rencana untuk melakukan pengembangan bisnis dapat segera dilakukan

2. Salah satu upaya yang dapat dilakukan untuk memecahkan masalah harga pakan ikan yang cenderung semakin mahal adalah secara bertahap mengubah bahan baku pakan ikan berbasis impor dan produk utama menjadi berbasis bahan baku lokal dan produk sampingan, dengan tanpa mengabaikan standar kualitasnya. Upaya tersebut memerlukan dukungan nyata dari segenap pemangku kepentingan industri pakan ikan, dalam rangka mewujudkan Indonesia swasembada pakan ikan.

3. Pengembangan SCM yang menjadi salah satu rumusan strategi operasi dalam analisis SWOT dan mendapat prioritas pertama dalam AHP perlu ditindaklanjuti dengan riset-riset yang mendalam tentang SCM, baik yang terkait dengan kinerja, resiko, juga model SCM-nya. Dalam lingkup yang lebih luas riset tentang model industri pakan ikan berbasis lokal dan produk sampingan menarik untuk dilakukan.

\section{DAFTAR PUSTAKA}

David FR. 2011. Manajemen Strategis Konsep. Buku 1 Edisi 12. Penerbit Salemba Empat. Jakarta.

Ellitan L dan Anatan L. 2008. Manajemen Strategi Operasi : Teori dan Riset di Indonesia. Alfabeta, Bandung.

Gaspersz V. 2005. Production Planning and Inventori Control. Vincent Fondation dan PT. Gramedia Pustaka Utama. Jakarta 
Grant RM. 1999. Analisis Strategi Kontemporer. Edisi Kedua. Penerbit Erlangga. Jakarta.

Handajani H dan Widodo W. 2010. Nutrisi Pakan Ikan. UMM Press. Malang

Heizer J dan Render B. 2009. Manajemen Operasi. Buku 1 Edisi 9. Penerbit Salemba Empat. Jakarta

Hunger, D. , Thomas W. 2010. Manajemen Strategi. Yogyakarta: Andi

Marimin dan Maghfiroh N. 2010. Aplikasi Teknik Pengambilan Keputusan dalam Manajemen Rantai Pasok. IPB Press. Bogor

Porter ME. 1985. Competitive Advantage,Creating and Sustaining Superior Performance. The Free Press New York

Render Barry, et.al.. 2009. Quantitative Analysis for Management. Tenth Edition Pearson Prentice Hall. New Jersey

Saaty,T.L. 1991. Pengambilan Keputusan Bagi Para Pemimpin (terjemahan) PT. Pustaka Binaman Pressindo. Jakarta

Sukirno dan Sriharti. 2003. Pengembangan Sistem Produksi Pakan Ikan di Pilot Plant Pakan UPT BPTTG LIPI Subang.

Taha HA., 2007, Operations Research : an Introduction, third edition, Macmillan Publishing Co. Inc, New York 